\title{
Long-run corporate tax avoidance: Evidence from Tehran Stock Exchange
}

\author{
Mehran Matinfard $^{\mathrm{a}^{*}}$ and Mojtaba Kazemi Juybari ${ }^{\mathrm{b}}$
}

\begin{abstract}
${ }^{a}$ Assist. Prof. \& Faculty Member, Department of Accounting, School of Management and Human Sciences, Tehran North Branch, Islamic Azad University (IAU), Tehran, Iran

${ }^{b}$ Department of Accounting, School of Management and Human Sciences, Tehran North Branch, Islamic Azad University (IAU), Tehran, Iran C H R O N I C L E A B S T R A C T

Article history:

Received June 5, 2015

Received in revised format July

162016

Accepted September 142016

Available online

September 142016

Keywords:

Avoidance of paying taxes

Economic value added

The primary objective of this research is to investigate the relationship between tax avoidance, income and cash held in companies listed on the Tehran Stock Exchange from 2009 to 2013. In this regard, avoidance of paying taxes is independent variables and criteria for evaluating financial performance; namely return on assets, return on average equities, economic value added, market value added, and the ratio of free cash flow are considered as dependent variables. Firm size and financial leverage are also considered as control variables. In general, the statistical method used in this research is correlation and regression. The results of the research showed that there was a significant and reverse relationship between avoidance of paying taxes and performance evaluation criteria, cash held.
\end{abstract}

Return on assets

Market value added (c) 2017 Growing Science Ltd. All rights reserved.

\section{Introduction}

Due to adverse effects which tax evasion has on the economy of the country, attention and further investigation are needed in this area, because tax evasion causes that the revenues of requirements for the government are not provided and as a result, services that the government should provide, are not presented. Therefore, the research in this area seems essential (Feld \& Tyran, 2002). Also, the results of the research can provide causes of improvement of tax system and the severity of many of the problems and economic imbalances such as the budget deficit and inflation are eased and the government plays a more important role in economy (Bräutigam, 2008). On the other hand, cash can be considered an important item of current assets in the process of implementation of the company's operations and for-profit entities. One of the important tasks of financial management is to forecast appropriate flows of cash entry and exit; in other words, cash is among the most important jobs for the financial management process (Ghani, 2013). The importance of cash is so essential that one of the purposes of accounting and financial reporting is to predict the future cash flows of the firms (Daneshfard, 2012). In addition, information asymmetry due to low quality of accounting information results in increasing the company's cost of capital and funding from financial markets would not be in

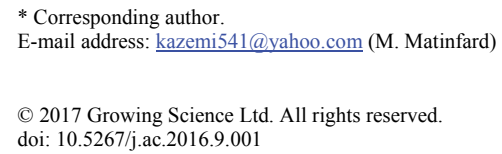


the interest of the company; therefore, most companies prefer to hold cash to cover their expenses as much as possible (Allingham \& Sandmo, 1972; Sameti et al., 2010; John, 2012).

\section{Problem statement}

Infrastructure needed to evaluate the performance of companies plays an important role for market capitalization and capital market, in turns, plays a vital role in boosting the economy. This market activates not only stagnant money and capital through companies, but also serves as an indicator of economic prosperity. Therefore, focusing on this market and basic fundamentals of decision-making is essential. The primary objective of most investors is to commensurate returns with their investments. If the company is successful to create value, not only investors and people inside the companies but also more broadly the community will benefit of creating value. Performance measurement in the decision-making process regarding the important role of the capital market is the most important topics in the field of financial economics; therefore, the performance of economic and financial measures is essential to evaluate the operating performance of companies (Yitzhaki, 1974). On the other hand, cash management depends on the demand for cash in the company. Cash management objective is to maximize shareholder wealth through limiting the levels of cash in the company. Cash must be kept at a level which creates a balance between the cost of holding sufficient cash and cash cost. In addition, corporate value will also be affected by cash management because cash levels of investment entails increase of other costs that are affected by levels of net working capital. Both increasing and reducing capital net in working entail the balance of free cash flows in the future and, in turn, changes in company valuation (Shue, 2006). One way to increase government tax revenues and achieve revenue targets is to attempt to pay tax. In this regard, governments meet the people's needs by providing free services on how to take advantage of a variety of financial principles and practices. On the other hand, if tax compliance is considered voluntary compliance of taxpayers to tax law and tax duties, in this case, noncompliance means the non-compliance to laws and regulations and legal obligations. However, the degree of tax compliance in each country is a measure of the efficiency of the tax system of the country and the rate of non-compliance can be measured by the tax gap (JafariSamimi, Amoli Diva, 2010).

In most countries, the bulk of the sources of government revenue is funded through taxes. Tax share of total public revenues among countries is different and the amount depends on the level of development and their economic structure. In the meantime, tax evasion and tax avoidance in countries have caused that tax income of the countries is always less than from what is estimated. In tax evasion, economic factors avoid from right reporting about their income from labor or capital including paying tax. In fact, they are doing a kind of unofficial action which taxes are kept away from the eyes of government officials and tax of the country, but in tax avoidance, economic factors are not concerned that their action is be disclosed (Dyreng et al., 2008). Avoidance of tax originates from legal gaps in the tax code and economic factors to reduce the ability to pay tax. There are three groups of avoidance of taxes including organizational, legal and structural in the tax system which organizational factors have the greatest impacts on the creation of tax avoidance. In fact, tax is often regarded as a burden by the organizations and managers tend to have lower taxes. On the other hand, as mentioned earlier, decision making to determine the amount of cash reserves (cash) has been always discussed as one of the factors considered by managers in the finance literature (Shahnoushi, 2010).

The major advantage of cash holdings in inefficient capital markets is to increase the company's ability to use valuable investment opportunities and avoid expensive external financing. If the wrong choice of external financing costs or costs of financial crises is very high, the companies will be trying to keep high liquidity in order to deal with unexpected shortage of cash and also financing for investments which have a positive net worth for the company. Therefore, in this study we are seeking to answer the questions whether or not cash holdings by listed companies on the Tehran Stock Exchange can be considered as one of the main motives of tax avoidance by managers of the companies. Given the importance of financial problems in the economy and tax evasion as one of the biggest problems of tax 
matters, this research investigates the relationship between avoidance of tax on income and cash held in companies listed on the Tehran Stock Exchange.

\section{Review of literature}

Mirmoahammadi et al. (2012) investigated the impact of factors influencing improving tax compliance, tax (legal entities) from the perspective of tax employees in Tehran. The main purpose of this research is to investigate the relationship between avoidance of tax on income and cash held in companies listed on the Tehran Stock Exchange so that we can observe more compliance of the tax payers to increase efficiency and effectiveness of tax system using these factors. The statistical population of 233 people of this research includes tax staff of Administration of Large Taxpayers Tax in Tehran that a sample of 95 patients was selected from the community. Research results showed that awareness of taxpayers on laws and regulations of taxes and duties, actions of tax crimes with respect to taxpayers and appropriate use of tax revenues and notification of them to taxpayers had a positive effect on compliance of taxpayers. Sadeqi and Shakibaee (2001) studied the effects of profit management on the relationship between free cash flow and shareholder value in manufacturing companies between 2005 and 2011 by using multivariate linear regression. The results show that there was a significant and direct relationship between free cash flows and shareholder value. Also, the results of the research indicated that the managers of these companies tend to increase free cash flows and ultimately, shareholder value and wealth by the use of earnings management tool (Torgler, 2001).

\section{Hypotheses}

Main hypothesis: There is a significant relationship between avoidance of tax on income and cash held in companies listed on the Tehran Stock Exchange.

\section{Sub hypotheses:}

1. There is a significant relationship between avoidance of paying taxes and return on assets.

2. There is a significant relationship between avoidance of paying taxes and annual return rate of stock.

3. There is a significant relationship between avoidance of paying taxes and economic value added.

4. There is a significant relationship between avoidance of paying taxes and market value added.

5. There is a significant relationship between avoidance of paying taxes and the ratio of free cash flow of the company.

Research population includes all companies listed on the Tehran Stock Exchange.

On the sample, the following restrictions are taken into account. In other words, among the statistical society, the companies are selected according to the following conditions:

- They must be listed on Tehran Stock Exchange by the end of March 2009 and their fiscal year must end in March.

- The companies must not be changed their financial year during the periods under consideration.

- Financial information needed for this research in the period 2009 to 2013 must be fully available.

- They must not be possessed to banks, financial institutions (investment companies, financial intermediaries, holding companies, leasing); they must be production companies because financial information disclosure and corporate governance structure are different. 
According to the above conditions, the sampling has been done and among all the companies on the Tehran Stock Exchange from 2009 to 2013 in 5-year period,91 companies using systematic elimination were selected as sample testing.

\section{Research method}

This research is an applied one in terms of classification in the purpose and in terms of method, this is quasi-experimental and from the kind of ex post facto. Also, this research is descriptive - correlational in the classification of the research in terms of methodology and data collection and this is used of the methodology of the market.

\section{Research findings}

Table 1

Descriptive analysis of the variables

\begin{tabular}{llllllllll}
\hline & Research variable & Number & Mean & SD & Variance & Skewness & Elongation & \multicolumn{2}{c}{$\begin{array}{l}\text { Distortion of coefficients } \\
\text { Skewness }\end{array}$} \\
Elongation
\end{tabular}

The number of observations in descriptive statistics related to the companies is 455 (91 companies in 5 years). The highest mean is related to the variable of firm size and the lowest mean is related to the variable of return on assets and economic value added for the company. The highest standard deviation is related to the variable of financial leverage of the company and the lowest standard deviation is related to the variable of return on assets. In the variables of return on assets (ROA), economic value added (EVA), given that statistics of skewness coefficient deviation is greater than the absolute value of 96.1 ; therefore, the distributions of the variables have severe deviation compared with a normal distribution, but the statistics of deviation of variable slenderness coefficient ratio is smaller than the absolute value of 96.1; therefore, the variable curve has no deviation compared to normal distribution. Positive skewness indicates a remote observation of the distribution right side and negative strain indicates low density of markers around the central indicators. Therefore, variable distribution is asymmetric and distribution curve is short and different from normal distribution and in other variables, given that the statistics of skewness coefficient deviation and kurtosis is larger than the absolute value of 96.1; therefore, distribution and curve has a severe deviation compared to normal distribution. These indicators state that remote viewing is located on right slope of the distribution and density of the observations in central indices is more severe and in general, the variable distribution has a serious difference with the normal distribution. In this survey, Kolmogorov-Smirnov as well as Shapiro-Wilk and Jarque- bera are used to examine the distribution of the study variables.

Table 2

The results of Kolmogorov-Smirnov as well as Shapiro-Wilk and Jarque- bera tests

\begin{tabular}{|c|c|c|c|c|c|c|c|}
\hline \multirow{2}{*}{ Row } & \multirow{2}{*}{$\begin{array}{l}\text { Research } \\
\text { variables }\end{array}$} & \multicolumn{2}{|c|}{ Kolmogorov-Smirnov } & \multicolumn{2}{|c|}{ Shapiro-Wilk } & \multicolumn{2}{|c|}{ Jarque- bera } \\
\hline & & Statistic & Error level & Statistic & Error level & Statistic & Error level \\
\hline 1 & MVA & .144 & .000 & .899 & .000 & 104.9432 & 0.000000 \\
\hline 2 & ROA & .283 & .000 & .295 & .000 & 30.16421 & 0.000000 \\
\hline 3 & FL & .384 & .000 & .268 & .000 & 52916.97 & 0.000000 \\
\hline 4 & SIZE & .086 & .000 & .952 & .000 & 95.87926 & 0.000000 \\
\hline 5 & SRE & .148 & .000 & .896 & .000 & 110.9454 & 0.000000 \\
\hline 6 & EVA & .283 & .000 & .295 & .000 & 29.76175 & 0.000000 \\
\hline 7 & $\mathrm{CFF}$ & .115 & .000 & .762 & .000 & 59.14921 & 0.000000 \\
\hline 8 & BTD & .293 & .000 & .286 & .000 & 34.58361 & 0.000000 \\
\hline
\end{tabular}


As it can be seen, according to the results of each three tests, none of the variables for normal distribution has been observed. Table 3 shows the results of Pearson correlation test.

Table 3

The results of Pearson correlation of research variables

\begin{tabular}{lcccc}
\hline Independent variables & Indicator & Tax avoidance & Firm size & Financial leverage \\
\hline Tax avoidance & Coefficient & 1 & .000 & $.095\left(^{*}\right)$ \\
& Error level & & 1.000 & .042 \\
\hline Firm size & Coefficient & .000 & 1 & .006 \\
& Error level & 1.000 & .006 & .892 \\
\hline Financial leverage & Coefficient & $.095\left(^{*}\right)$ & .892 & 1 \\
& Error level & .042 & & \\
\hline
\end{tabular}

The results of Pearson correlation coefficient indicate that the relationships among any of the three explanatory variables including: an independent variable and two control variables are not severe to create multicollinearity relationships in models. The amount of 0.60 and more leads to create multicollinearity relationship. Finally, simultaneous arrival of three explanatory variables in the model does not result in creating the problem of multicollinearity.

Compound regression analysis can be executed in two pooled and panel ways. Limer test is used for decision making in the use of pooled or panel models and Hausman test is used for the use of fixed effects or cross-section random. The results of Limer test have supported from the performance of Pooled for the periods and first model sections and for the periods of third model, but Limer test results for the periods and sections of second, fourth and fifth models have approved the application of the panel. The results of Hausman test have supported from the performance of random effects for estimating third and fifth models and the performance of fixed effects for the periods and the sections of second and fourth models and the performance of fixed effects for the periods of fifth models. The results of the studies related to selecting the appropriate models to examine the relationship among the variables in five research model are shown in the table below.

Table 3

The results of research models for pooled or panel model and type of models

\begin{tabular}{llllccc}
\hline Model & Test & \multicolumn{3}{c}{ Limer test } & \multicolumn{3}{c}{ Hausman test } \\
\cline { 3 - 7 } & & F statistic & Error level & Chi-square & Error level & Result \\
\hline Model 1 & Panel & 0.448058 & 0.7738 & - & - & - \\
& Pool & 1.178206 & 0.1510 & - & - & - \\
\hline Model 2 & Panel & 126.516127 & 0.0000 & 191.346900 & 0.0000 & Fixed \\
& Pool & 1.988193 & 0.0000 & 94.713319 & 0.0000 & Fixed \\
\hline Model 3 & Panel & 0.612988 & 0.6535 & - & - & \\
& Pool & 1.395091 & 0.0181 & 3.172469 & 0.3658 & Random \\
\hline Model 4 & Panel & 142.627018 & 0.0000 & 248.745733 & 0.0000 & Fixed \\
& Pool & 1.692536 & 0.0000 & 81.384513 & 0.0000 & Fixed \\
\hline Model 5 & Panel & 15.137212 & 0.0000 & 59.592157 & 0.0000 & Fixed \\
& Pool & 1.497717 & 0.0054 & 7.119401 & 0.0682 & Random \\
\hline
\end{tabular}

According to the results, the significance level calculated for each of the five models is less than 0.05 ; as a result, the relationship between the explanatory and dependent variables in the linear models has been evaluated. Moreover, Jarque- beratest is used to test the remaining of distribution of the model. Given that statistic of Jarque- bera for all models is larger than the critical value, in other words, the significance level is significantly smaller than 0.05 , as a result, the remaining distribution of these models is not normal. Durbin - Watson is used to determine the independent model errors. If the values are between 1.50 and 2.50, the model is no autocorrelation. Durbin - Watson statistic for all five models in the range of expected values is located that this has supported from the absence of autocorrelation models. 
Table 4

The results of linearity correlation test, remaining distribution and Durbin - Watson

\begin{tabular}{|c|c|c|c|c|c|c|}
\hline \multirow[t]{2}{*}{ Research } & \multicolumn{2}{|c|}{ Linear correlation test } & \multicolumn{2}{|c|}{ Durbin - Watson test } & \multicolumn{2}{|c|}{ Test of remaining distribution } \\
\hline & F statistic & Error level & Calculate & Desirable & Jarque- bera & Error level \\
\hline Model 1 & 2.683489 & 0.046254 & 1.881982 & $2.5-1.5$ & 25.78933 & 0.000003 \\
\hline Model 2 & 8.464802 & 0.000000 & 1.985956 & $2.5-1.5$ & 271.3293 & 0.000000 \\
\hline Model 3 & 2.652863 & 0.048169 & 1.827518 & $2.5-1.5$ & 29.22115 & 0.000000 \\
\hline Model 4 & 8.859799 & 0.000000 & 2.042645 & $2.5-1.5$ & 313.7615 & 0.000000 \\
\hline Model 5 & 11.35915 & 0.000000 & 1.738759 & $2.5-1.5$ & 177.8166 & 0.000000 \\
\hline
\end{tabular}

To answer the questions and to achieve the objectives of the study, the process of five models with regression analysis combined is conducted.

\subsection{First model - the study of the effect of tax avoidance on the rate of return on assets}

In this model, according to Limer and Hausman test results for the periods and sections, pooled model is selected. Durbin-Watson statistic with 1.88 ranged between 1.50 and 2.50 is located indicating no correlation between the error terms in the regression equation. Fisher statistics of the model with 2.68 includes a significance level of less than 0.05 which is due to linear relationship of at least one of the explanatory variables and the dependent variable. Although the distribution of the variables and remaining distribution of the model are not normal, their distribution is single exponential. Using the White test, elimination of the anisotropy is performed. In this model, none of the explanatory variables yields a strong relationship together to create a multicollinearity relationship. T-statistics calculated for the independent variable of tax avoidance is less than critical value -1.96 and -2.58 and the significance level is less than 0.05 and 0.01 which supported from significant and adverse effect of avoidance of paying tax rate of return on assets in the level of $99 \%$ confidence. T-statistics calculated for the financial leverage and firm size variables is less than absolute 1.96 and 1.64 and the significance level is more than 0.05 and 0.10 which did not support the effect of financial leverage and firm size variables on the rate of return on assets. The coefficient of determination has shown that about $2 \%$ of the changes of the rate of return on assets are explained by three factors. Therefore, despite the significant impact of independent variable on dependent variable, the first sub hypothesis of the research is confirmed.

\section{Table 5}

The results of the regression analysis and the impact of tax avoidance on the rate of return on assets

Dependent variable: the rate of return on assets, number of periods: 5 years, the number of section: 91 companies, healthy number observed: 455

\begin{tabular}{|c|c|c|c|c|c|c|}
\hline \multicolumn{3}{|c|}{ Variable name } & \multirow{2}{*}{$\begin{array}{l}\text { Coefficient } \\
0.399381\end{array}$} & \multirow{2}{*}{$\begin{array}{l}\text { Standard error } \\
0.041327\end{array}$} & \multirow{2}{*}{$\begin{array}{l}\text { T-statistic } \\
9.663880\end{array}$} & \multirow{2}{*}{$\begin{array}{l}\text { Significance level } \\
0.0000\end{array}$} \\
\hline$\beta_{0}$ & $\mathrm{C}$ & Intercept & & & & \\
\hline$\beta_{1}$ & BTD & Tax avoidance & -0.128824 & 0.039077 & -3.296639 & 0.0011 \\
\hline$\beta_{2}$ & FL & Financial leverage & 0.000215 & 0.000359 & 0.597897 & 0.5502 \\
\hline$\beta_{3}$ & SIZE & Firm size & -0.000842 & 0.006830 & -0.123326 & 0.9019 \\
\hline \multirow{2}{*}{\multicolumn{3}{|c|}{$\begin{array}{l}\text { Coefficient of determination } \\
\text { Corrected coefficient of determination }\end{array}$}} & 0.017537 & \multicolumn{2}{|l|}{ Durbin - Watson } & 1.881982 \\
\hline & & & 0.011002 & \multicolumn{2}{|l|}{ F statistic } & 2.683489 \\
\hline
\end{tabular}

\subsection{Second model - the study of the effect of tax avoidance on the annual return rate of stock}

In this model, according to Limer and Hausman test results for the periods and sections, panel model with fixed effects is selected. Durbin-Watson statistics with 1.98 ranged between 1.50 and 2.50 is located indicating no correlation between the error sentences in the regression equation. Fisher statistics of the model with 8.47 includes a significance level of less than 0.05 which is due to linear relationship of at least one of the explanatory variables and the dependent variable. Although the distribution of the variables and remaining distribution of the model are not normal, their distribution is single exponential. Using the White test, elimination of the anisotropy is performed. In this model, none of 
the explanatory variables maintains a strong relationship together to create a multicollinearity relationship. T-statistics calculated for the independent variable of tax avoidance is less than critical value -1.96 and -2.58 and the significance level is less than 0.05 and 0.01 which is significant and adverse effect of avoidance of paying tax rate of return on assets in the level of $99 \%$ confidence. Tstatistics calculated for the financial leverage and firm size variables is less than absolute 1.96 and 1.64 and the significance level is more than 0.05 and 0.10 which did not support from the effect of financial leverage and firm size variables on the rate of return on assets. The coefficient of determination has shown that about $70 \%$ of the changes of the rate of return on assets are explained by three factors. Therefore, despite the significant impact of independent variable on dependent variable, the second sub hypothesis of the research is confirmed.

\section{Table 6}

The results of the regression analysis on the effect of tax avoidance on annual rate of return on stock

Dependent variable: the annual rate of return on stock, number of periods: 5 years, the number of section: 91 companies, healthy number observed: 455

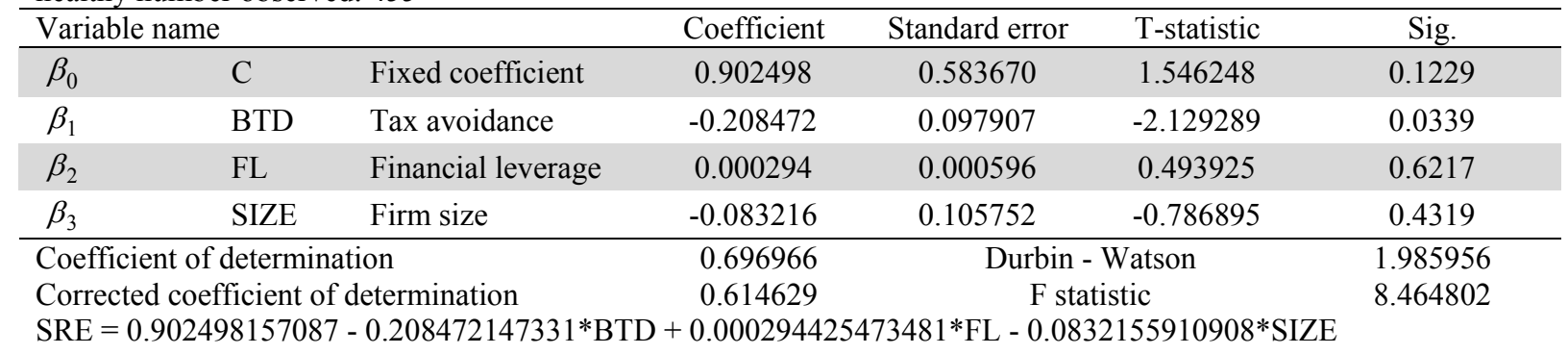

\subsection{Third model - the study of the effect of tax avoidance on economic value added}

In this model, according to Limer and Hausman test results pooled model is selected for the periods and sections of panel model with fixed effects are selected. Durbin-Watson statistics with 1.98 ranged between 1.50 and 2.50 is located indicating no correlation between the error sentences in the regression equation. Fisher statistics of the model with 2.65 includes a significance level of less than 0.05 which is due to linear relationship of at least one of the explanatory variables and the dependent variable. Although the distribution of the variables and remaining distribution of the model are not normal, their distributions are single exponential. Using the White test, elimination of the anisotropy is performed. In this model, none of the explanatory variables maintains a strong relationship together to create a multicollinearity relationship. T-statistics calculated for the independent variable of tax avoidance is less than critical value -1.96 and -2.58 and the significance level is less than 0.05 and more than 0.01 which supports the adverse effect of avoidance of paying tax rate of return on assets in the level of $99 \%$ confidence.

Table 7

The results of the regression analysis for the effect of tax avoidance on EVA

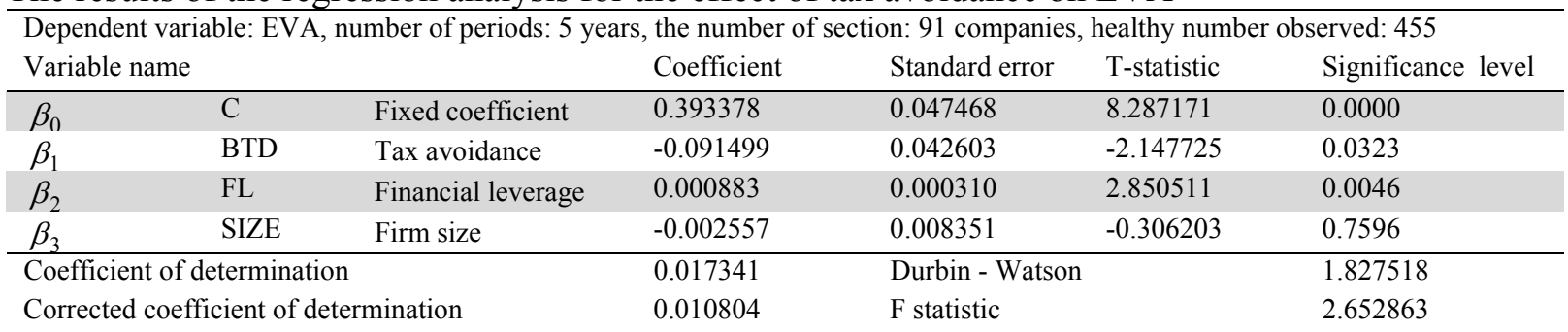

$\mathrm{EVA}=0.393378178942-0.0914986982757 * \mathrm{BTD}+0.000882763173679 * \mathrm{FL}-0.00255702676453 * \mathrm{SIZE}$

T-statistics calculated for the financial leverage variable is more than absolute1.96 and 2.58 and the significance level is less than 0.05 and 0.01 and for the firm size variable is less than absolute 1.96 and 
1.64 which supports the direct and significant effect of financial leverage in the level $99 \%$ of confidence but does not support the effect of firm size on EVA. The coefficient of determination has shown that about $2 \%$ of the changes of the rate of return on assets are explained by three factors. Therefore, despite the significant impact of independent variable on dependent variable, the third sub hypothesis of the research is confirmed.

\subsection{Fourth model - the study of the effect of tax avoidance on MVA}

In this model, according to Limer and Hausman test results for the periods and sections, panel model with fixed effects is selected. Durbin-Watson statistics with 2.04 ranged between 1.50 and 2.50 is located indicating no correlation between the error sentences in the regression equation. Fisher statistics of the model with 8.86 includes a significance level of less than 0.05 which is due to linear relationship of at least one of the explanatory variables and the dependent variable. Although the distribution of the variables and remaining distribution of the model are not normal, their distributions are single exponential. Using the White test, elimination of the anisotropy is performed. In this model, none of the explanatory variables has a strong relationship together to create a multicollinearity relationship. Tstatistics calculated for the independent variable of tax avoidance is less than critical value -1.96 and 2.58 and the significance level is less than 0.05 and 0.01 which supports the adverse effect of avoidance of paying tax on MVA in the level of $99 \%$ confidence. T-statistics calculated for the financial leverage and firm size variables is less than absolute 1.96 and 1.64 and the significance level is more than 0.05 and 0.10 which does not support from the effect of financial leverage and firm size variables on the rate of return on assets. The coefficient of determination has shown that about $71 \%$ of the changes of MVA on assets are explained by three factors. Therefore, despite the significant impact of independent variable on dependent variable, the fourth sub hypothesis of the research is confirmed.

\section{Table 8}

The results of regression analysis for the effect of tax avoidance on MVA

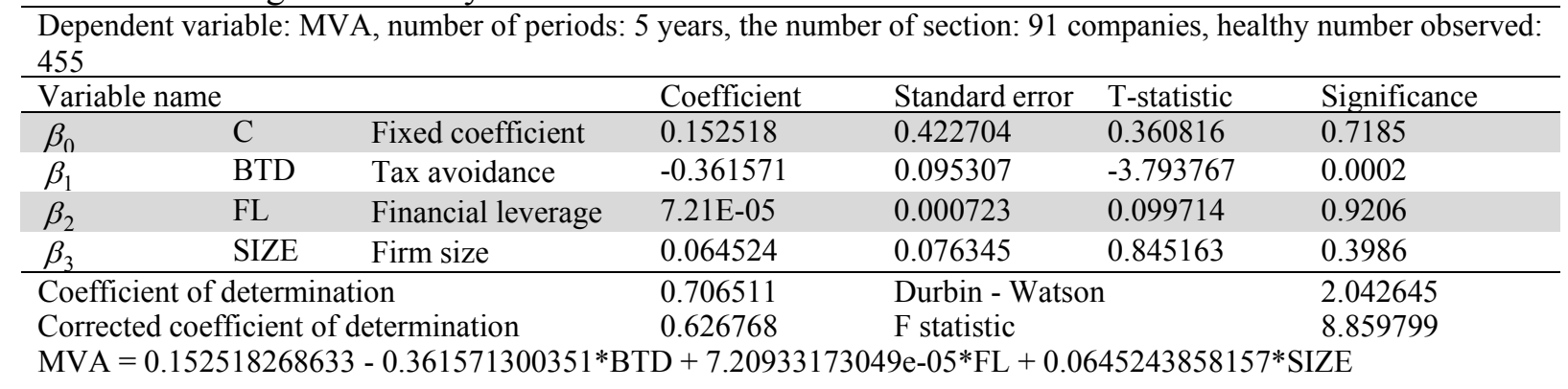

\subsection{Fifth model - the study of the effect of tax avoidance on the ratio of free cash flow of the company}

In this model, according to Limer and Hausman test results pooled model is selected for the periods and sections of panel model with fixed effects are selected. Durbin-Watson statistics with 1.74. Fisher statistics of the model with 11.36 includes a significance level of less than 0.05 which is due to linear relationship of at least one of the explanatory variables and the dependent variable. Although the distribution of the variables and remaining distribution of the model are not normal, their distribution is single exponential. Using the White test, elimination of the anisotropy is performed. In this model, none of the explanatory variables maintains a strong relationship together to create a multicollinearity relationship. T-statistics calculated for the independent variable of tax avoidance is less than critical value -1.96 and -2.58 and the significance level is less than 0.05 and 0.01 which is significant and supports the effect of avoidance of paying tax on the ratio of free cash flow of the company in the level of $99 \%$ confidence. T-statistics calculated for the financial leverage and firm size variables is less than absolute 1.96 and 1.64 and the significance level is more than 0.05 and 0.10 which did not support the effect of financial leverage and firm size variables on the rate of return on assets. The coefficient of 
determination has shown that about $15 \%$ of the changes of the ratio of free cash flow of the company are explained by three factors. Therefore, despite the significant impact of independent variable on dependent variable, the fifth sub hypothesis of the research is confirmed.

\section{Table 9}

The results of the regression analysis results for the effect of tax avoidance on the ratio of free cash flow of the company

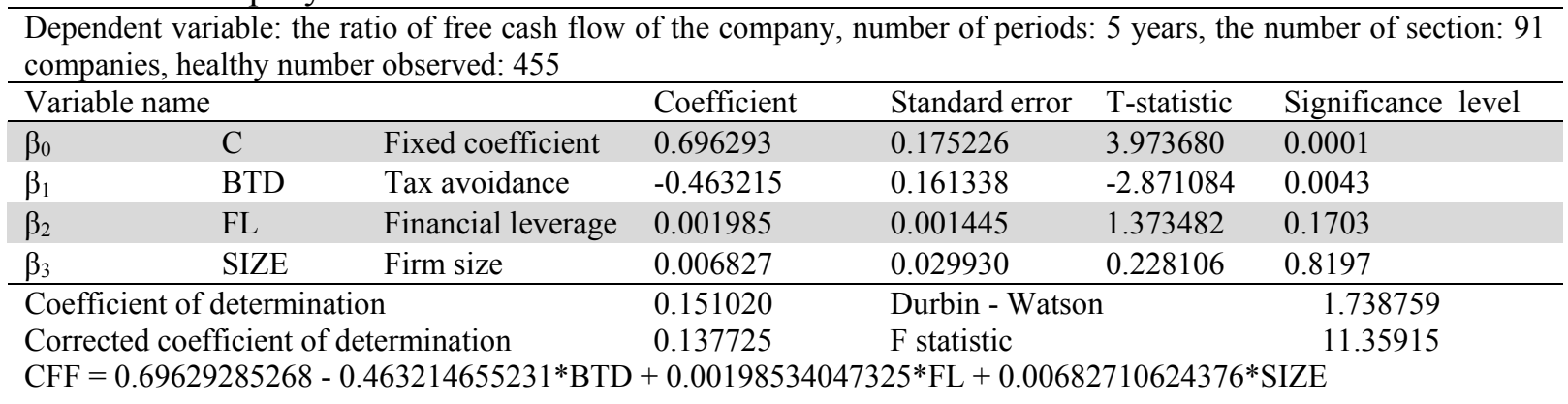

\section{The results of testing research hypotheses}

The research hypotheses are studied and examined through regression analysis combined based on coefficients of the impact derived from five models which then, according to the results of the study, the analyses carried out have been referred.

\subsection{Main hypothesis}

There is a significant relationship between avoidance of tax on income and cash held in companies listed on the Tehran Stock Exchange.

According to theoretical basis of the research, it is expected that in the population of the study, avoidance of paying taxes may have an effect on performance and cash held in companies listed on the Tehran Stock Exchange. According to the results, five research models have supported from adverse effects of avoidance of paying taxes on performance and cash held by listed companies in Tehran Stock Exchange. Therefore, according to evidence gathered from data of the study and the results of five research hypotheses, this main hypothesis is confirmed.

\subsection{First sub hypothesis}

There is a significant relationship between avoidance of paying taxes and return on assets.

According to theoretical basis of the research, it is expected that in the population of the study of Tehran stock companies, avoidance of paying taxes may have an effect on return on the assets. To confirm or deny this claim, null hypothesis indicates no effect from the tax avoidance of the rate of return on assets and the opposite hypothesis indicates the existence of tax avoidance effect on the rate of return on the assets which both of them are tested. Therefore, the null and opposite hypothesis has been proposed as follows and statistics test indicators are listed based on the results obtained from the first model.

$$
\left\{\begin{array} { l } 
{ H 0 : \beta _ { \mathrm { ROA. \textrm {BTD } } } = 0 } \\
{ H 1 : \beta _ { \mathrm { ROA. \textrm {BTD } } } \neq 0 }
\end{array} \Rightarrow \left\{\begin{array}{l}
\beta=-0.128824, \mathrm{~T}=-3.296639, \mathrm{P}=0.0011 \\
\mathrm{~T}_{\mathrm{OB}}<-1.96 \&-2.58, \quad P<.05 \& .01
\end{array}\right.\right.
$$

The test of this hypothesis and decision making on the basis of the results of the first model regression analysis are performed. The coefficient of the effect of avoidance of paying tax rate of return on assets in the value -0.128 includes critical statistics calculated according to the value -3.290 . Since the statistics calculated is less than the critical value -1.96 and -2.58 and in other words, the significance level of the test is less than 0.05 and 0.01 , therefore, evidence collected has a necessary ability to reject 
the null hypothesis at the level of $99 \%$ of the confidence and finally, the first sub-study hypothesis is reversely confirmed and it can be claimed that there is a significant relationship between avoidance of tax and return on the assets.

\subsection{Second sub hypothesis}

There is a significant relationship between avoidance of paying taxes and the annual return rate of stock.

According to theoretical basis of the research, it is expected that in the population of the study of Tehran stock companies, avoidance of paying taxes may have an effect on the annual return rate of stock. To confirm or deny this claim, null hypothesis indicates no effect from the tax avoidance on the annual return rate of stock and the opposite hypothesis indicates the existence of tax avoidance effect on the annual return rate of stock which both of them is tested. Therefore, the null and opposite hypothesis has been proposed as follows and statistics test indicators are listed based on the results obtained from the second model.

$$
\left\{\begin{array} { l } 
{ H 0 : \beta _ { \text { SRE.BTD } } = 0 } \\
{ H 1 : \beta _ { \text { SRE.BTD } } \neq 0 }
\end{array} \Rightarrow \left\{\begin{array}{l}
\beta=-0.208472, \mathrm{~T}=-2.129289, \mathrm{P}=0.1229 \\
\mathrm{~T}_{\mathrm{OB}}<-1.96 \quad \&>-2.58, \quad P<.05 \quad \&>.01
\end{array}\right.\right.
$$

The test of this hypothesis and decision making on the basis of the results of the second model regression analysis are performed. The coefficient of the effect of avoidance of paying tax of the annual return rate of stock in the value -0.208472 includes critical statistics calculated according to the value2.129. Since the statistics calculated is less than the critical value -1.96 and more than -2.58 and in other words, the significance level of the test is less than 0.05 and 0.01 , therefore, evidence collected has a necessary ability to reject the null hypothesis at the level of $95 \%$ of the confidence and finally, the second sub-study hypothesis is reversely confirmed and it can be claimed that there is a significant relationship between avoidance of tax and the annual return rate of stock.

\subsection{Third sub hypothesis}

There is a significant relationship between avoidance of paying taxes and EVA.

According to theoretical basis of the research, it is expected that in the population of the study of Tehran stock companies, avoidance of paying taxes may have an effect on EVA. To confirm or deny this claim, null hypothesis indicates no effect from tax avoidance on EVA and the opposite hypothesis indicates the existence of tax avoidance effect on EVA which both of them is tested. Therefore, the null and opposite hypothesis has been proposed as follows and statistics test indicators are listed based on the results obtained from the third model.

$$
\left\{\begin{array} { l } 
{ H 0 : \beta _ { \text { EVA.BTD } } = 0 } \\
{ H 1 : \beta _ { \text { EVA.BTD } } \neq 0 }
\end{array} \Rightarrow \left\{\begin{array}{l}
\beta=-0.091499, \mathrm{~T}=-2.147725, \mathrm{P}=0.0323 \\
\mathrm{~T}_{\mathrm{OB}}<-1.96 \&>-2.58, \quad P<.05 \quad \&>.01
\end{array}\right.\right.
$$

The test of this hypothesis and decision making on the basis of the results of the third model regression analysis are performed. The coefficient of the effect of avoidance of paying tax on EVA of the stock in the value -0.0914992 includes critical statistics calculated according to the value-2.148. Since the statistics calculated is less than the critical value -1.96 and more than -2.58 and in other words, the significance level of the test is less than 0.05 and 0.01 , therefore, evidence collected has a necessary ability to reject the null hypothesis at the level of $95 \%$ of the confidence and finally, the third sub-study hypothesis is reversely confirmed and it can be claimed that there is a significant relationship between avoidance of tax and EVA. 
There is a significant relationship between avoidance of paying taxes and MVA.

According to theoretical basis of the research, it is expected that in the population of the study of Tehran stock companies, avoidance of paying taxes may have an effect on MVA. To confirm or deny this claim, null hypothesis indicates no effect from tax avoidance on MVA and the opposite hypothesis indicates the existence of tax avoidance effect on MVA which both of them is tested. Therefore, the null and opposite hypothesis has been proposed as follows and statistics test indicators are listed based on the results obtained from the fourth model.

$$
\left\{\begin{array} { l } 
{ H 0 : \beta _ { \text { MVA.BTD } } = 0 } \\
{ H 1 : \beta _ { \text { MVA.BTD } } \neq 0 }
\end{array} \Rightarrow \left\{\begin{array}{l}
\beta=-0.361571, \mathrm{~T}=-3.793767, \mathrm{P}=0.0002 \\
\mathrm{~T}_{\mathrm{OB}}<-1.96 \&-2.58, \quad P<.05 \& .01
\end{array}\right.\right.
$$

The test of this hypothesis and decision making on the basis of the results of the fourth model regression analysis are performed. The coefficient of the effect of avoidance of paying tax on MVA of the stock in the value -0.361571 includes critical statistics calculated according to the value-3.794. Since the statistics calculated is less than the critical value -1.96 and more than -2.58 and in other words, the significance level of the test is less than 0.05 and 0.01 , therefore, evidence collected has a necessary ability to reject the null hypothesis at the level of $95 \%$ of the confidence and finally, the fourth substudy hypothesis is reversely confirmed and it can be claimed that there is a significant relationship between avoidance of tax and MVA.

\subsection{Fifth sub hypothesis}

There is a significant relationship between avoidance of paying taxes and the ratio of free cash flow of the company.

According to theoretical basis of the research, it is expected that in the population of the study of Tehran stock companies, avoidance of paying taxes may have an effect on the ratio of free cash flow of the company. To confirm or deny this claim, null hypothesis indicates no effect from tax avoidance on the ratio of free cash flow of the company and the opposite hypothesis indicates the existence of tax avoidance effect on the ratio of free cash flow of the company which both of them is tested. Therefore, the null and opposite hypothesis has been proposed as follows and statistics test indicators are listed based on the results obtained from the fifth model.

$$
\left\{\begin{array} { l } 
{ H 0 : \beta _ { \mathrm { CFF } . \mathrm { BTD } } = 0 } \\
{ H 1 : \beta _ { \mathrm { CFF } . \mathrm { BTD } } \neq 0 }
\end{array} \Rightarrow \left\{\begin{array}{l}
\beta=-0.361571, \mathrm{~T}=-3.793767, \mathrm{P}=0.0002 \\
\mathrm{~T}_{\mathrm{OB}}<-1.96 \&-2.58, \quad P<.05 \& .01
\end{array}\right.\right.
$$

The test of this hypothesis and decision making on the basis of the results of the fifth model regression analysis are performed. The coefficient of the effect of avoidance of paying tax on the ratio of free cash flow of the company of the stock in the value -0.361571 includes critical statistics calculated according to the value-3.794. Since the statistics calculated is less than the critical value -1.96 and more than 2.58 and in other words, the significance level of the test is less than 0.05 and 0.01 , therefore, evidence collected has a necessary ability to reject the null hypothesis at the level of $95 \%$ of the confidence and finally, the fifth sub-study hypothesis is reversely confirmed and it can be claimed that there is a significant relationship between avoidance of tax and the ratio of free cash flow of the company. 


\section{Summary of the results of research hypotheses}

According to the data collected of the statistical population of firms listed on the Tehran Stock Exchange in the period between 2009 to 2013, and using regression analysis combined, five hypotheses are tested. There are 455 observations for each of research variables in this study. According to the five regression analysis combined, all five sub-study hypothesis are accepted significantly and reversely. Therefore, avoidance of paying taxes on the Tehran Stock Exchange Companies results in reducing market value added, return on assets, annual stock return, economic value added and the ratio of free cash flow of the company. As a result, main hypothesis of the research on "there is a significant relationship between avoidance of tax on income and cash held in companies listed on the Tehran Stock Exchange." is accepted. Summary of the results with hypotheses and results of null and opposite hypotheses are shown in the table below.

Table 10

The summary of the results of null and opposite hypotheses and final result of test of hypotheses

\begin{tabular}{|c|c|c|c|c|c|}
\hline \multirow[t]{2}{*}{$\begin{array}{l}\text { Number of the } \\
\text { hypothesis }^{1}\end{array}$} & \multirow[t]{2}{*}{$\begin{array}{l}\text { Independent } \\
\text { variable }\end{array}$} & \multirow[t]{2}{*}{$\begin{array}{l}\text { Dependent } \\
\text { variable }\end{array}$} & \multicolumn{2}{|c|}{$\begin{array}{c}\text { null and opposite } \\
\text { hypotheses }\end{array}$} & \multirow[t]{2}{*}{ Test result } \\
\hline & & & $\beta=0$ & $\beta \neq 0$ & \\
\hline Main hypothesis & Avoidance of tax & $\begin{array}{l}\text { Performance and } \\
\text { cash }\end{array}$ & - & - & $\begin{array}{l}\text { The effect of the independent variable on the } \\
\text { dependent variables is significant. }\end{array}$ \\
\hline Sub-hypotheses 1 & Avoidance of tax & Return on assets & $x$ & $\checkmark$ & $\begin{array}{l}\text { The effect at the level } 99 \% \text { of the confidence } \\
\text { is significant and reverse. }\end{array}$ \\
\hline Sub-hypotheses 2 & Avoidance of tax & $\begin{array}{l}\text { The annual return } \\
\text { rate of stock }\end{array}$ & $x$ & $\checkmark$ & $\begin{array}{l}\text { The effect at the level } 99 \% \text { of the confidence } \\
\text { is significant and reverse. }\end{array}$ \\
\hline Sub-hypotheses 3 & Avoidance of tax & EVA & $x$ & $\checkmark$ & $\begin{array}{l}\text { The effect at the level } 99 \% \text { of the confidence } \\
\text { is significant and reverse. }\end{array}$ \\
\hline Sub-hypotheses 4 & Avoidance of tax & MVA & $x$ & $\checkmark$ & $\begin{array}{l}\text { The effect at the level } 99 \% \text { of the confidence } \\
\text { is significant and reverse. }\end{array}$ \\
\hline Sub-hypotheses 5 & Avoidance of tax & $\begin{array}{l}\text { The ratio of free } \\
\text { cash flow of the } \\
\text { company }\end{array}$ & $x$ & $\checkmark$ & $\begin{array}{l}\text { The effect at the level } 99 \% \text { of the confidence } \\
\text { is significant and reverse. }\end{array}$ \\
\hline
\end{tabular}

\section{Conclusion and discussion}

One of the economic outcomes that managers must consider in determining corporate tax policy is its impact on the company's financial performance. This view leads to the conclusion that the managers should consider a mid-point of an advantage of cash flows increased from paying taxes reduced against risk price increased for the company. Despite the relationship between two concepts of tax risk and tax avoidance, it must be said that each one examines and measures different aspects of tax policies of a company. Generally, tax avoidance is a fair use of tax evasions to minimize tax pressures. Tax risk is concentrated on uniformity of consequences of corporate tax avoidance over time instead of minimizing the tax liability of the company in a given period. It should be noted that the effective tax planning is a strategic balance between minimizing taxes and increasing the value of the company.

From economic perspective, tax revenue has been a major source of government finance in funding and provided to acquire macroeconomic purposes. From management perspective, maximizing shareholder wealth is one of the basic assumptions for financial management. Based on this assumption, on the one hand, management should increase the earnings of the corporation and on the other hand,

\footnotetext{
${ }^{1}$. Main hypothesis: There is a significant relationship between avoidance of tax on income and cash held in companies listed on the Tehran Stock Exchange. Sub hypotheses :

2. First sub hypothesis: There is a significant relationship between avoidance of paying taxes and return on assets.

3. Second sub hypothesis: There is a significant relationship between avoidance of paying taxes and annual return rate of stock.

4.Third sub hypothesis: There is a significant relationship between avoidance of paying taxes and economic value added.

5. Fourth sub hypothesis: There is a significant relationship between avoidance of paying taxes and market value added.

6.Fifth sub hypothesis: There is a significant relationship between avoidance of paying taxes and the ratio of free cash flow of the company.
} 
this should reduce the risk of the company. Corporate income tax results in reducing future earnings of the company. Therefore, one of measurements which can increase the company value and shareholder wealth is to use strategies to reduce the business tax.

The findings from this research can be summarized as follows.

Based on the results of the research hypotheses, there is a significant and reverse relationship between avoidance of tax on income and criteria of assessment held in companies listed on the Tehran Stock Exchange from 2009 to 2013, which means that whatever financial managers of the companies know legal ways of tax evasion, and by resorting to these rules, their aim is to pay less taxes, financial resources and cash of the company are reduced. This result could mean that the stock companies perform less risk for ways to avoid paying taxes which also indicates that there is an exact control on these companies on behalf of the Stock Organization. On the other hand, since the aim of these companies is to maximize the profit of shareholders, they do not intend to perform such methods and they prefer to pay the right tax evasion instead of tax avoidance of enhance cash flow and financial resources.

This study recommends suggestions for the Tehran Stock Exchange, government and economic officials as below based on evidence from the study and the results of testing:

Given the inverse relationship between tax avoidance and financial performance evaluation criteria, it seems that legal gaps do not lead to tax avoidance by companies listed on Tehran Stock Exchange. Therefore, it is recommended that since there is not an exact control for non-exchange companies, economists and officials and legislators stipulate some strategies to accept such companies' timely and correct payment of taxes so that the official abuse of tax laws (tax avoidance) are not met. Although the results suggest that now at least there is tax avoidance and evasion in the stock companies, deficiencies in existing laws, a lack of qualified experts and excise, decreasing tax rates in practice, tax unfair treatments, unfair tax rates, and delay in the tax system, taxpayer collusion and auditing, tax structuring and the lack of a strong central tax information should not be ignored and it is attempted that all companies cannot accept such ways instead of just right paying.

\section{Suggestions for future studies}

1. To study the relationship between avoidance of tax on firm performance during life cycle of the company and by dividing into growth opportunities of up and down.

2. To study the effect of ownership on the relationship between tax avoidance on firm performance.

3. The effect of income smoothing and earnings management to avoid paying taxes.

4. To study factors affecting avoid paying tax on performance of the company on the Tehran Stock Exchange companies using genetic algorithms and artificial neural networks.

\section{References}

Allingham, M. G., \& Sandmo, A. (1972). Income tax evasion: A.

Asadi, M., Hamidi Alamdari, S., \& Abdi, M.R. (2009). To study the effect of gradual elimination of subsidies on the proceeds of VAT. Journal of Economic Research and Policies, 20(4), 63-76.

Bräutigam, D. (2008). Introduction: taxation and state-building in developing countries. Taxation and state-building in developing countries: Capacity and consent, 1-33.

Daneshfard, A. (2012). Barriers to implementation of VAT law. Journal of Economics, 13, 147-159.

Dyreng, S. D., Hanlon, M., \& Maydew, E. L. (2008). Long-run corporate tax avoidance. The Accounting Review, 83(1), 61-82. 
Feld, L. P., \& Tyran, J. R. (2002). Tax evasion and voting: An experimental analysis. Kyklos, 55(2), 197-221.

Ghani, U. (2013). Taxation, State Building and Aid. Factsheet, Updated December Paris .

JafariSamimi, A., \& Salehnejad, H. (2008). A replacement of VAT for corporate tax and its impact on the government's budget. Accounting Reviews, 26-27.

John, H. (2012). Taxation, State Building and Aid. Factsheet, Updated December Paris. Available at www.oecd.org/dac/governance

Mirmoahammadi, A., Sadeqi, H., \& Shakibaee, A. (2012), evaluation of the factors influencing improving compliance of taxpayers. Mofid Journal, 2, 55-76.

Sadeqi, H., \& Shakibaee, A. (2001). Tax evasion and size of underground economy (using phase econometrics. Mofid Journal, 27, 55- 76.

Sameti, M., Tayyebi, K., \& Haji-Karami, M. (2010). Effect of value added tax and its impact on net exports and its comparison with corporate income tax in Iran and other Asian countries. Journal of Quantitative Economics (former economic studies), 1, 135-157.

Shahnoushi, M. (2010). To evaluate and identify strategies to green taxation and its impact on improving environmental indicators and Welfare, Department of Economic Affairs.

Shue, L. (2006). Guidance on tax compliance for business and accounting software and SAFT. Information Systems Control Journal, 2, 31.

Torgler, B. (2001). What do we know about tax morale and tax compliance?.Rivista internazionale di scienze economiche e commerciali, 48(3), 395-420.

Yitzhaki, S. (1974). Income tax evasion: A theoretical analysis. Journal of public economics, 3(2), 201202.

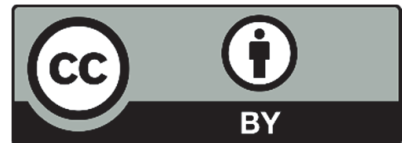

(C) 2016 by the authors; licensee Growing Science, Canada. This is an open access article distributed under the terms and conditions of the Creative Commons Attribution (CC-BY) license (http://creativecommons.org/licenses/by/4.0/). 